\title{
The Kinsloe Site (41GG3) on Rabbit Creek in the mid-Sabine River Basin, Gregg County, Texas
}

Timothy K. Perttula

Heritage Research Center, Stephen F. Austin State University

Follow this and additional works at: https://scholarworks.sfasu.edu/ita

Part of the American Material Culture Commons, Archaeological Anthropology Commons, Environmental Studies Commons, Other American Studies Commons, Other Arts and Humanities Commons, Other History of Art, Architecture, and Archaeology Commons, and the United States History Commons

Tell us how this article helped you.

This Article is brought to you for free and open access by the Center for Regional Heritage Research at SFA ScholarWorks. It has been accepted for inclusion in Index of Texas Archaeology: Open Access Gray Literature from the Lone Star State by an authorized editor of SFA ScholarWorks. For more information, please contact cdsscholarworks@sfasu.edu. 
The Kinsloe Site (41GG3) on Rabbit Creek in the mid-Sabine River Basin, Gregg County, Texas

\section{Creative Commons License}

\section{(c) (1) \&}

This work is licensed under a Creative Commons Attribution-NonCommercial 4.0 International License 


\section{The Kinsloe Site (41GG3) on Rabbit Creek in the mid-Sabine River Basin, Gregg County, Texas}

Timothy K. Perttula

\section{Introduction}

The Kinsloe site (41GG3) is on Rabbit Creek in the middle Sabine River basin a few miles north of Kilgore, Texas. The site is ca. $2 \mathrm{~km}$ west of the confluence of Rabbit Creek and the Sabine River. This site is one of a number of late $17^{\text {th }}$ to early $19^{\text {th }}$ century Caddo sites that have been associated with the Kinsloe focus or phase first recognized by Buddy C. Jones (1968; see also Fields and Gadus 2012:639643; Perttula 2007), and affiliated with Nadaco Caddo groups. Jones (1968:29-47 and Figure 3) provides a detailed summary of the local avocational archaeological work that had been done at the Kinsloe site, and mentions surface collections he had obtained from several areas of the site; these surface collections are now at the Gregg County Historical Museum in Longview, Texas (see below).

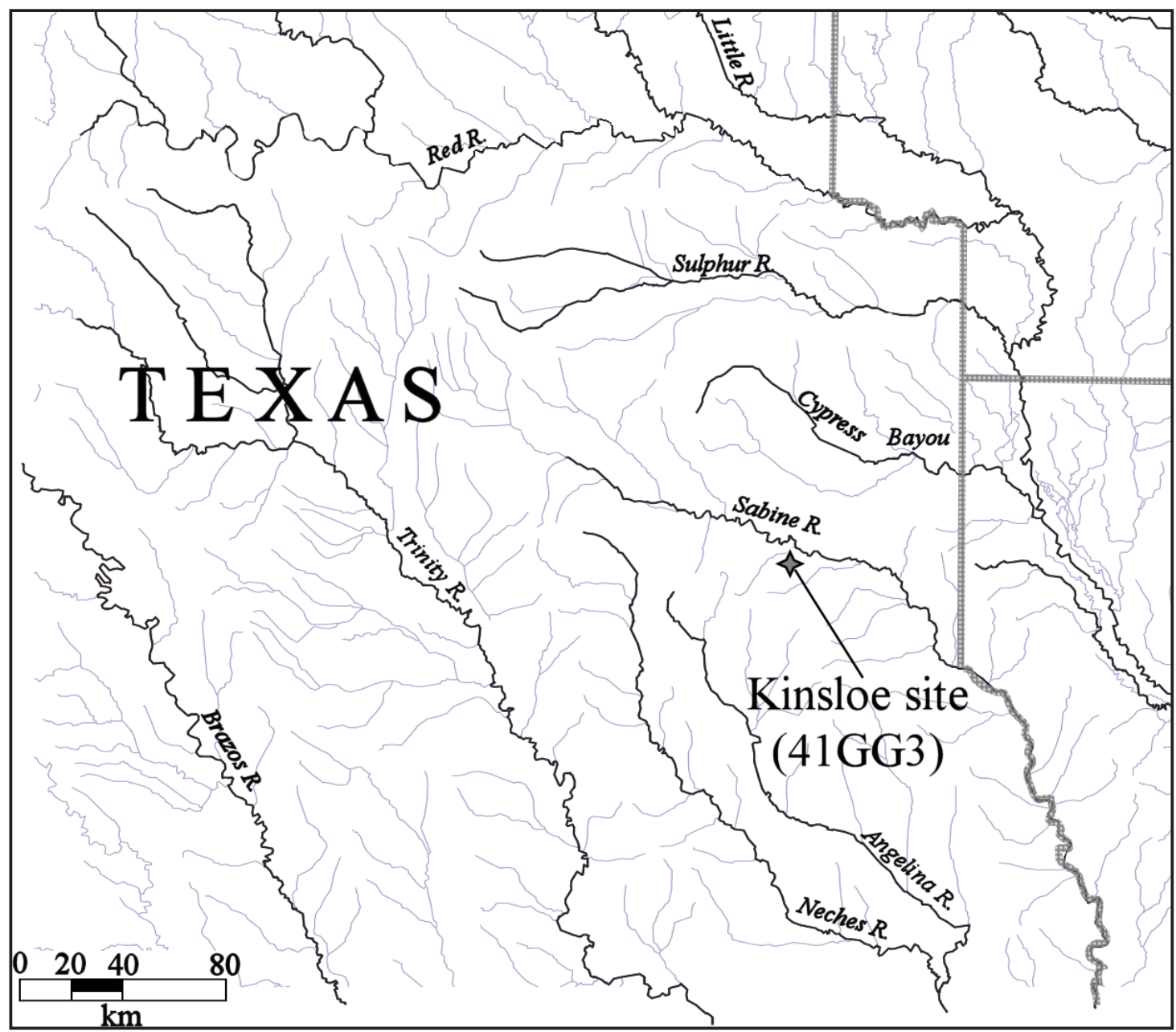

Figure 1. The location of the Kinsloe site (41GG3) in East Texas. 
The Kinsloe site was found by Magnolia employees in 1931 when an area of the Rabbit Creek floodplain and an alluvial fan/terrace was graded for the construction of pipelines and oil storage tanks (April 1931 letter from J. E. Pearce to A. T. Jackson, on file at TARL). A Mr. E. A. Fox, one of the employees, excavated 19 ancestral Caddo burials from the site by 1940, and several other individuals apparently excavated as many as 11 more burials there by that time. The collections obtained by Mr. Fox were later examined by Jones (1968) as part of his Master's thesis on Kinsloe focus/phase sites in East Texas. Jones also defined four site areas, A-D, with the Historic Caddo burials in Area C on an alluvial fan, and Areas A, B, and D to the west, north, and south; Area A is on the alluvial fan, Area B is on a floodplain rise, and Area D is on a prominent alluvial terrace ca. $150 \mathrm{~m}$ south of Area C (see Jones 1968:Figure 3).

However, recent investigations of the records and collections at the Texas Archeological Research Laboratory at The University of Texas at Austin (UT-TARL) indicate that there had been work done at the Kinsloe site in 1937 and 1940 that Buddy C. Jones had not been aware of and had not mentioned in his 1968 Master's thesis. I will discuss these investigations in the remainder of this article, as well as the ancestral Caddo material culture remains and European trade goods recovered in these investigations.

\section{Investigations}

Jack T. Hughes, then a high school student at Henderson High School in East Texas, but later a renowned professional archaeologist who worked most of his career in the Texas Panhandle until his death in 2001, excavated a burial at the Kinsloe site in 1937; he referred to the site in his own numbering system as IE-376. When Hughes graduated high school in 1937, he took his collections with him when he attended The University of Texas at Austin, and then he donated the collections to UT, where they remain in the TARL collections.

Hughes described the site as being on Rabbit Creek, about 2 miles north of the city of Kilgore, Texas. There are no notes at TARL that describe the circumstances of the work done there, but in addition to the one burial he excavated there, Hughes did recover a large assemblage of Late Paleoindian to Late Archaic dart points at the site, as well as several Early Caddo period arrow points. The burial excavated by Hughes had a number of associated funerary offerings, including two ceramic vessels, one bone tool, red ochre, marine shell beads, and several glass trade beads (see below).

\section{Investigations}

In April 1940, Gus E. Arnold of The University of Texas recorded the Kinsloe site as ET-730 as part of his 16 county archaeological survey in East Texas for the Works Progress Administration (WPA). Gus Arnold identified and recorded a number of ancestral Caddo sites during his 1939-1940 WPA-sponsored archaeological survey of East Texas (Im 1975). He had been advised by A. T. Jackson of UT in a March 26, 1940 letter, that a number of Indian burials had been found and excavated at the site by a Mr. E. A. Fox, and Jackson advised Arnold to talk with Mr. Fox about his work there, and to also obtain a surface collection of artifacts.

Arnold noted that the site covered between ca. 3-5 acres of floodplain rises and an alluvial terrace on the east side of Rabbit Creek. The Caddo cemetery with 19 individual burials covered a ca. $12.5 \times 15.2 \mathrm{~m}$ area, and there were other burials found across the site. These burials included as funerary offerings ceramic vessels, ceramic pipes, glass beads (according to Arnold, each of the burials had glass beads), iron knives, an iron axe or adze, as well as stone arrow points and celts. The majority of the burials were in an extended position in burial pits that were only ca. $15-45 \mathrm{~cm}$ below the surface, after the surface had been graded for construction purposes. He was able to draw and document several ancestral Caddo ceramic vessels in the Fox collection, and obtain a surface collection of ceramic vessel sherds from unknown areas on the site (see below). 


\section{8 and 1961 Investigations}

According to the records and collections on file at the Gregg County Historical Museum (Patti Haskins, February 17, 2016 personal communication), Buddy Jones had visited Mr. E. A. Fox in 1958 and 1961 to collect artifacts from the Kinsloe site (his site GC-61) and also to document Mr. Fox's large collection from burial excavations.

Bag 2003.08.3137 from cigar box A-14, labeled the "Fox burial site," namely the Area C burial area at the Kinsloe site (see Jones 1968:Figure 3), had (all of local lithic raw materials) hematite celt fragments, one petrified wood chopper, one worked cobble, possibly a chopper, with cortex on one end, two dart points, one thumbnail scraper, one petrified wood flake, as well as three flakes and one point fragment on non-local lithic raw materials. In this same area, Jones collected 23 ceramic vessel body sherds and 3 rim sherds. The body sherds included: 10 plain, and seven punctated, four brushed, one brushedpunctated, and one incised. The three rims have either horizontal brushed or engraved elements; the engraved rim is from a Holly Fine Engraved vessel. A second bag (Brown Bag 23. Labeled GC 61) is from "the hill behind Mr. Fox's house," namely Area D of the Kinsloe site (see Jones 1968:Figure 3). Another bag had an unidentified engraved rim sherd from a carinated bowl. A second bag, labeled Brown bag 30, GC 61, "Kilgore burial site ( Bead place)," had eight small body sherds, four with brushed decorations and four that were plain.

\section{Material Culture Remains}

\section{Vessels}

Arnold documented two small $(9.3 \mathrm{~cm}$ in height and $12.1 \mathrm{~cm}$ in diameter) Natchitoches Engraved bowls from the Kinsloe site (Figures 2a-d and 3a-b); these same vessels in the Fox collection were also documented by Jones (1968:36-37 and Plate 4a-b'). Vessel 2 has a red ochre-rich pigment rubbed in the engraved design on the vessel rim (Figure 3b). Arnold did not note the temper of either vessel, but Jones (1968:36) suggests they had a "fine clay grit" as temper (i.e., grog, or perhaps no visible temper inclusions).

Hughes recovered another Natchitoches Engraved bowl (represented by 23 sherds from an unreconstructed vessel) in a burial feature excavated in 1937 (Figure 4). This vessel was made with finelycrushed shell temper. The vessel rim has nested engraved triangles and negative ovals, while the vessel body has sets of curvilinear engraved lines with tick marks divided by negative ovals defined by crosshatched triangular and bracket-shaped elements.

A second vessel in the burial feature excavated in 1937 is an unreconstructed shell-tempered jar (Figure 5) represented by 25 rim and body sherds. The rim is plain, but the vessel body has a series of diagonal opposed incised triangle elements, as is seen in shell-tempered Ebarb Incised vessels from the Natchitoches, Louisiana, area (Gregory and Avery 2007:45-47).

Two other vessels from the site documented by Arnold are small $(\mathrm{ca} .3 .3-3.7 \mathrm{~cm}$ ) plain jars (Figure 6). Jones (1968: 38 and Plate 3d, f) included them in the then newly-defined Henderson Plain type.

\section{Ceramic Sherds}

Arnold collected a total of 129 ceramic vessel sherds from the surface of the Kinsloe site in 1940, from plain wares, utility wares, and fine wares (Table 1). Approximately 80 percent of the sherds are from grog-tempered vessels, another 12.4 percent are from bone-tempered vessels, and the remaining 7 percent are from shell-tempered vessels. Several of the grog-tempered base sherds are quite thick (i.e., 20-22 mm), and may be from Williams Plain vessels probably found in Formative to Early Caddo period contexts in non-burial areas (i.e., Areas A-B and D). 


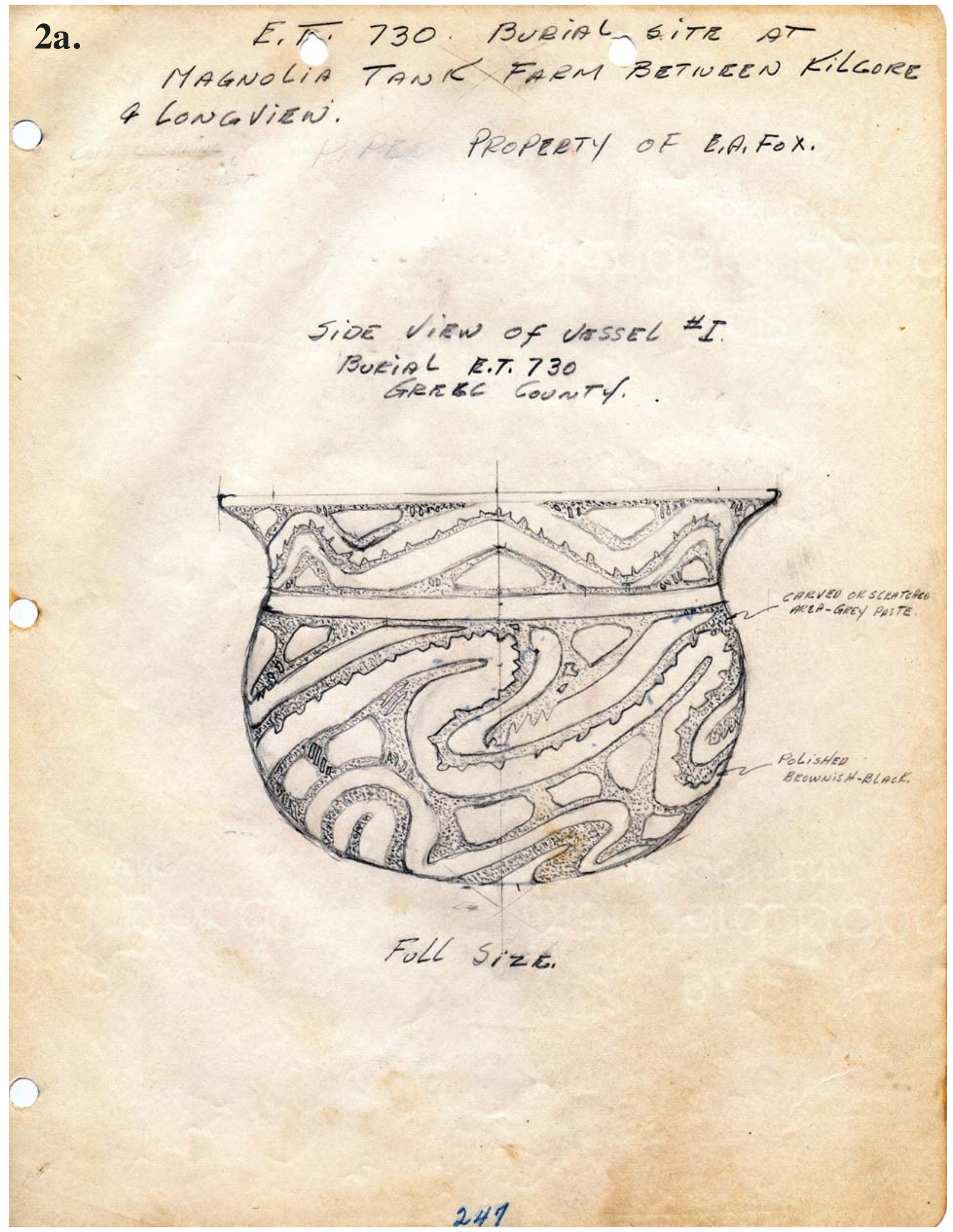

Figure 2. Natchitoches Engraved bowl, Vessel 1, from the Kinsloe site, original drawings (courtesy of TARL) by Gus Arnold: a, side view; b, bottom view of vessel; c, modern redrawing of Vessel 1; d, modern drawing of the engraved design on the vessel body and base. 


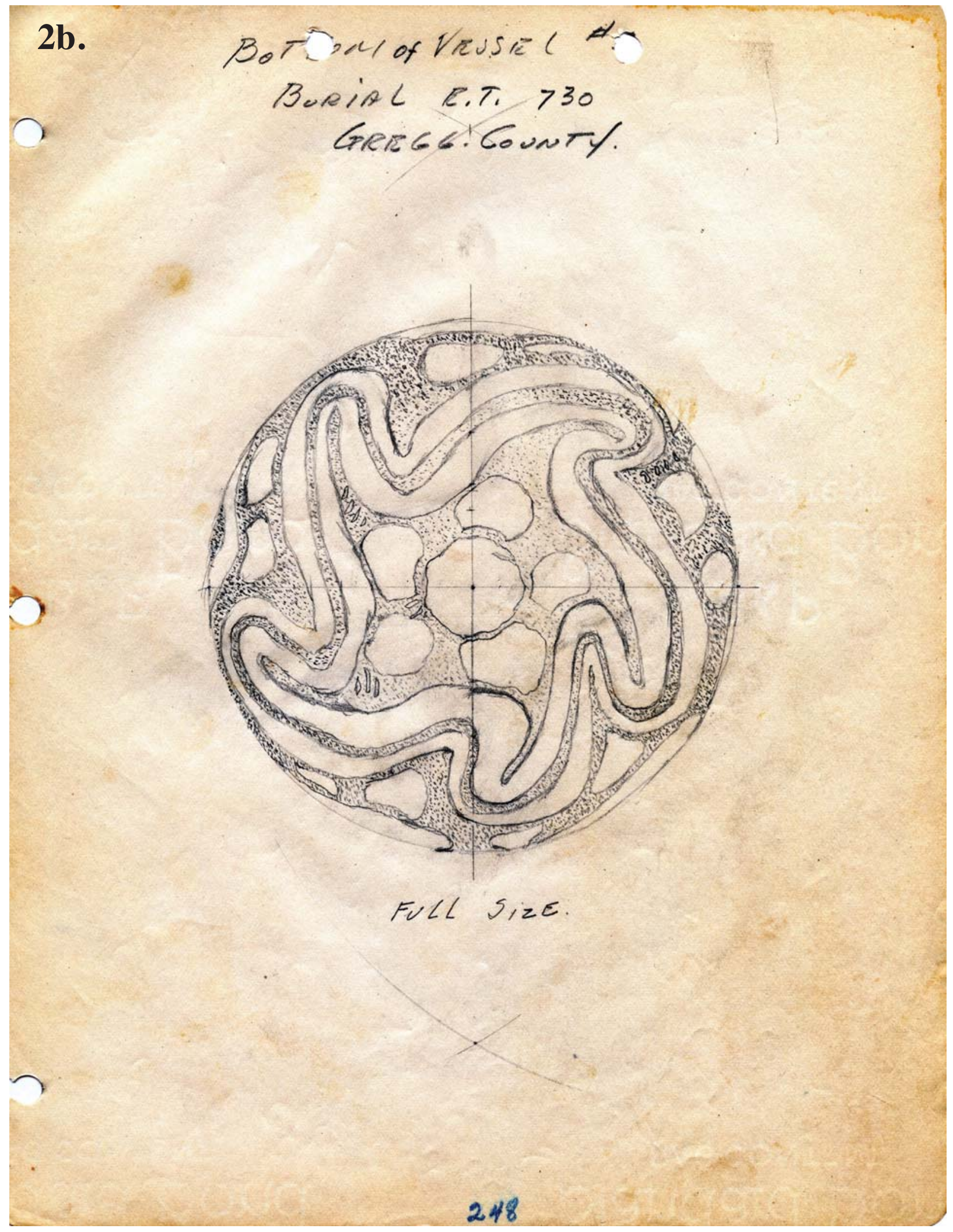

Figure 2., cont. 
80 Journal of Northeast Texas Archaeology 71 (2017)

2c.

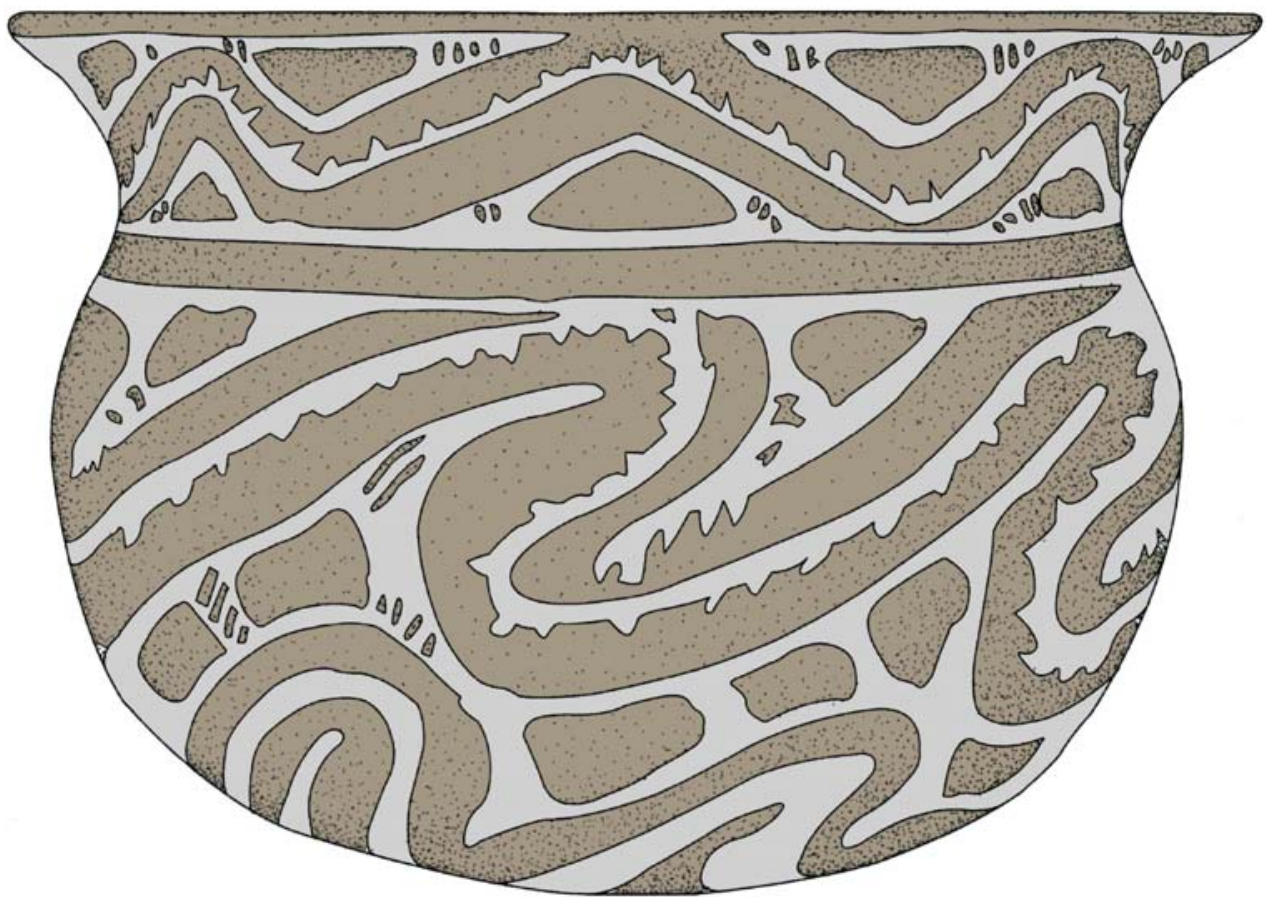

2d.

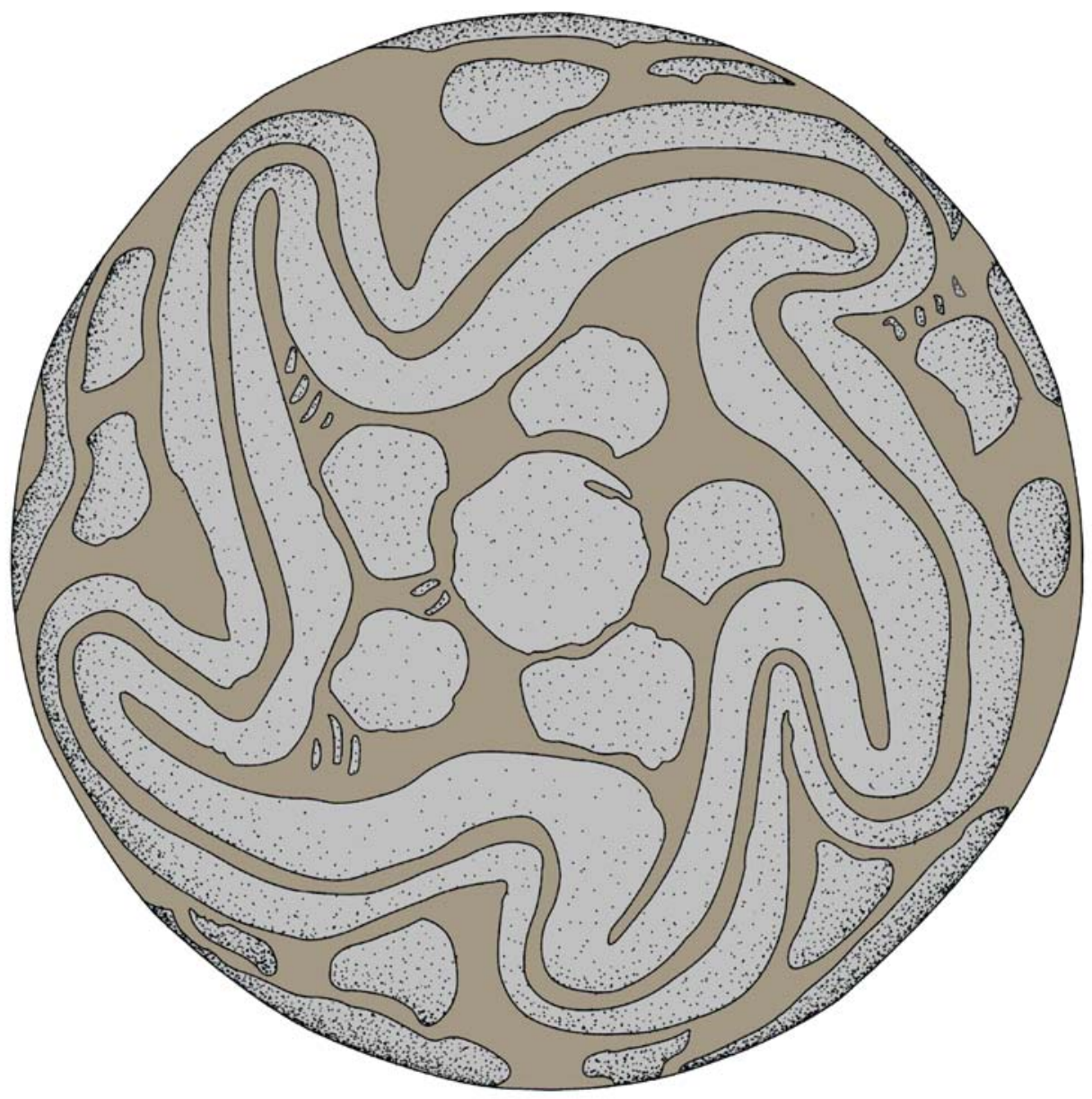

Figure 2., cont. 


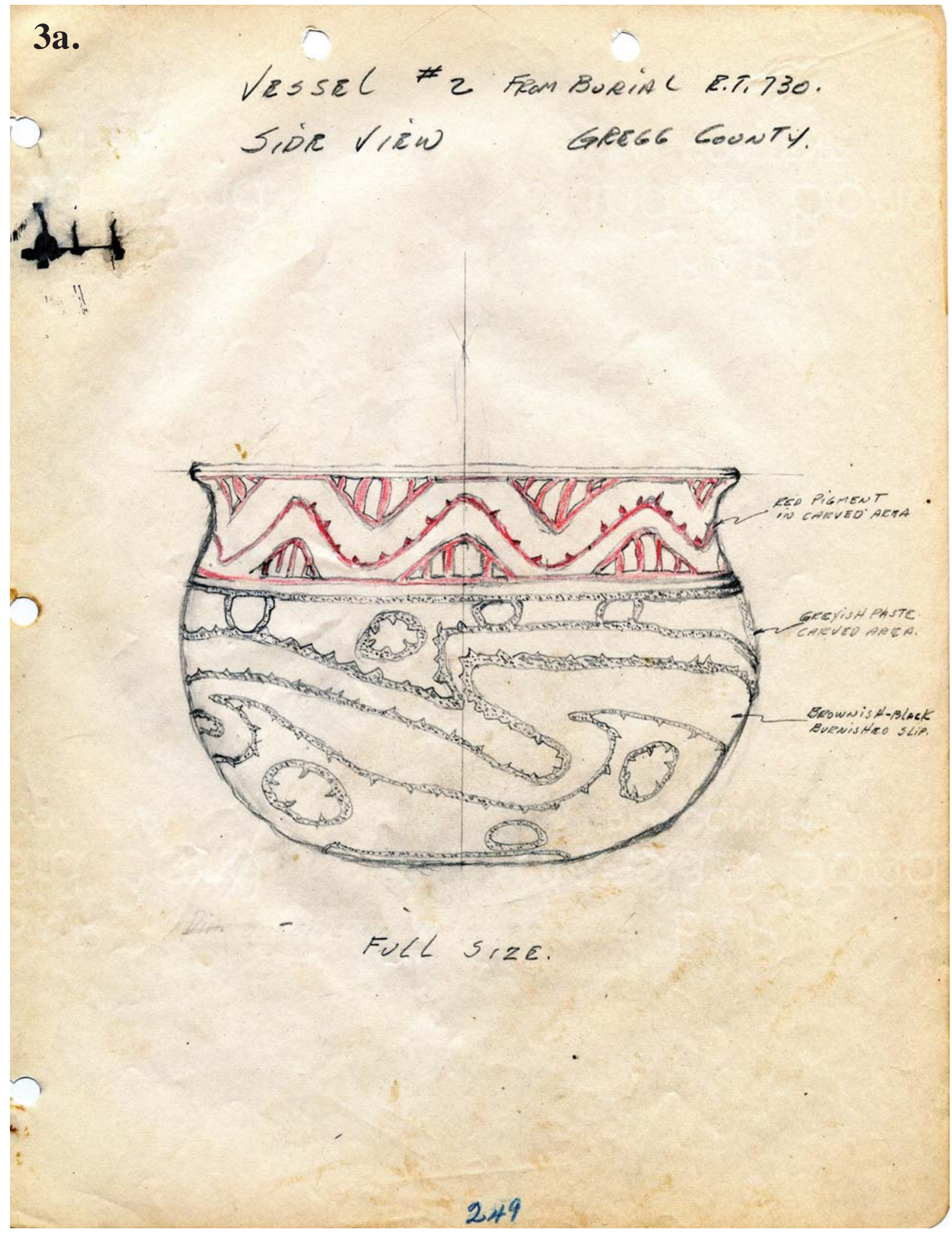

Figure 3. Natchitoches Engraved bowl, Vessel 2, from the Kinsloe site: a, original drawing by Arnold (courtesy of TARL); b, modern redrawing version of Vessel 2. 
$3 b$.

Figure 3., cont.
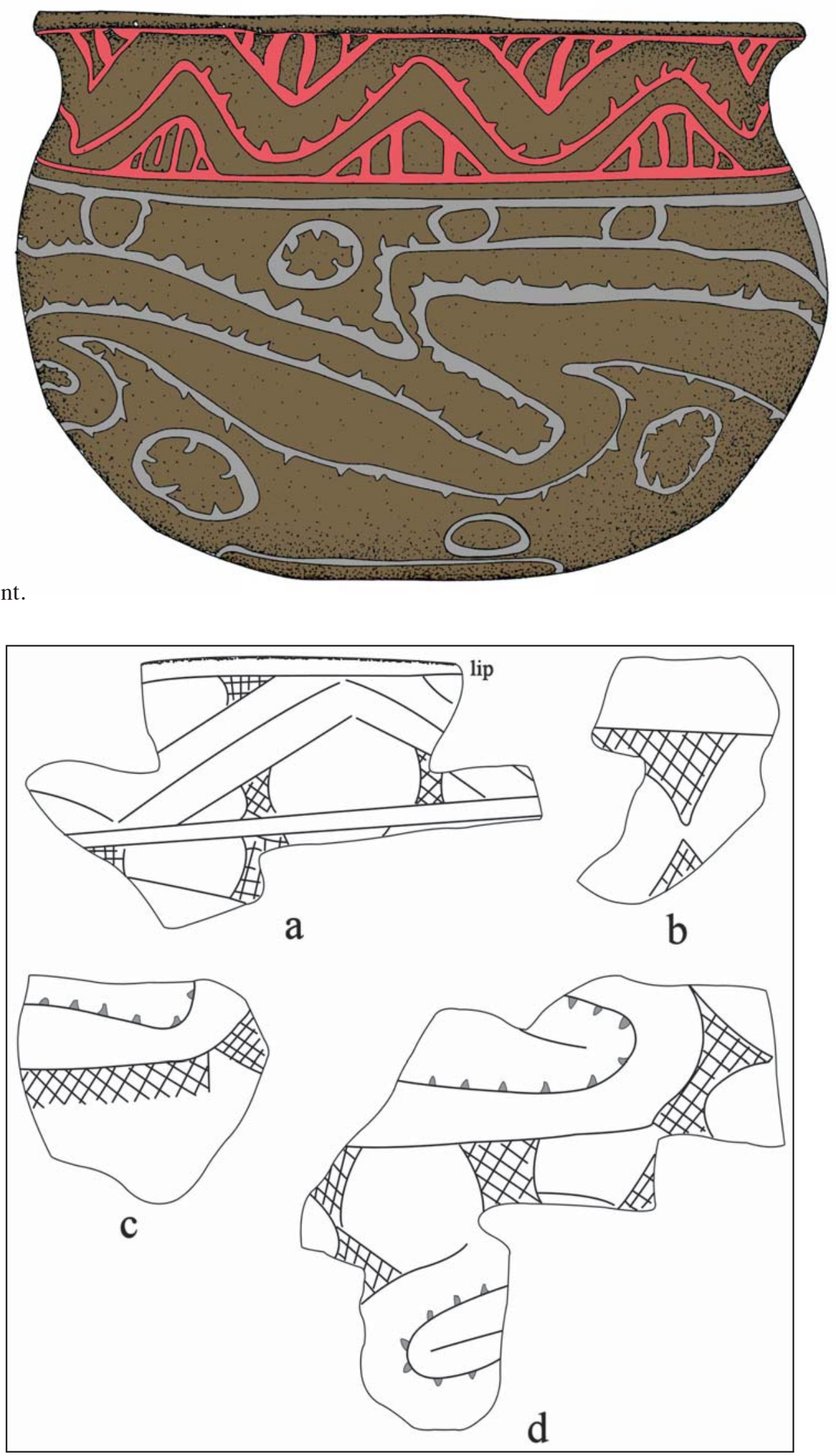

Figure 4. Decorative elements on Natchitoches Engraved bowl rim and body sherds from the Kinsloe site excavated in 1937. 


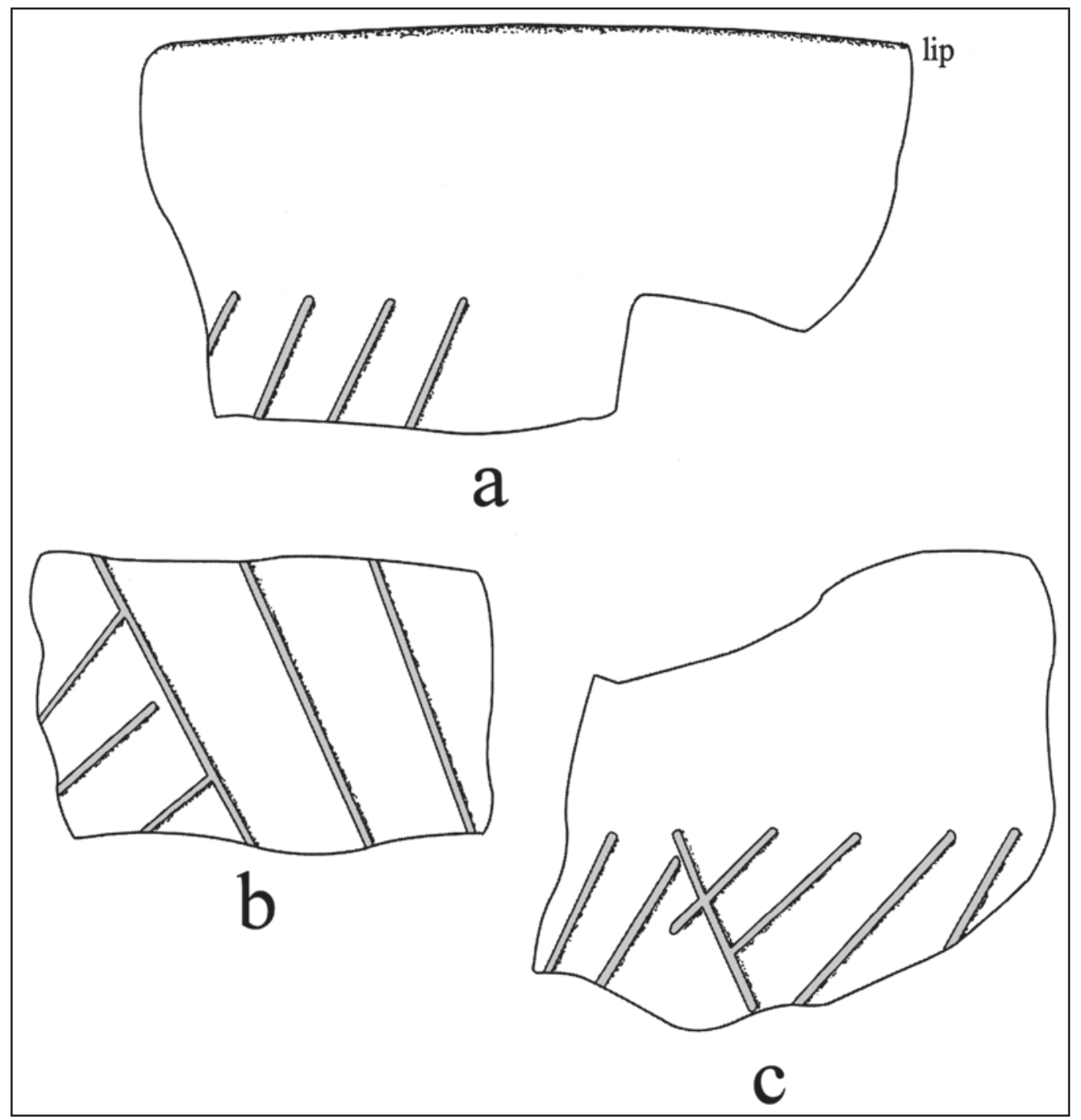

Figure 5. Decorative elements on Incised shell-tempered jar rim and body sherds from the Kinsloe site excavated in 1937.

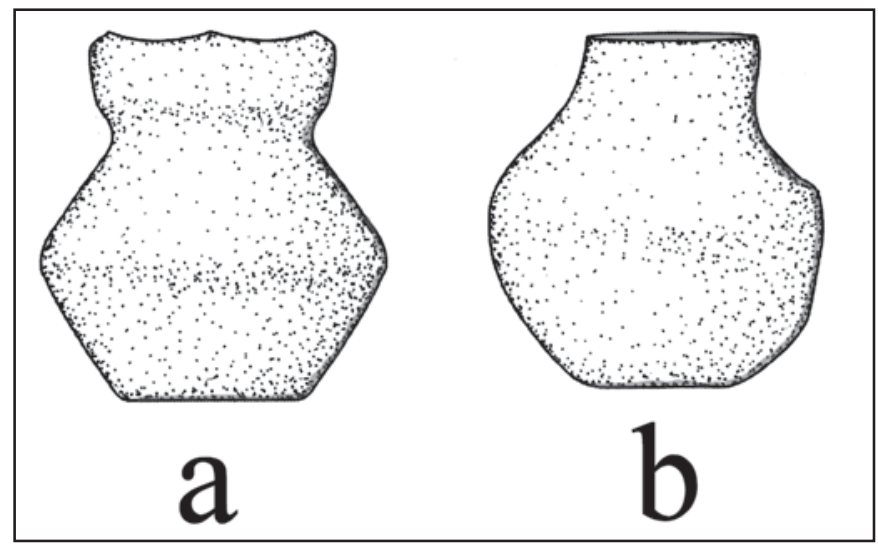

Figure 6. Small plain jars from the Kinsloe site excavated in 1937. 
Table 1. Ceramic sherds collected by G. E. Arnold from the Kinsloe site (41GG3) in 1940.

\begin{tabular}{lcccc}
\hline Ware & Grog-tempered & Bone-tempered & Shell-tempered & N \\
\hline Plain & 58 & 8 & 3 & 69 \\
Utility & 42 & 7 & 4 & 53 \\
Fine & 4 & 1 & 2 & 7 \\
\hline Totals & 104 & 16 & 9 & 129 \\
\hline
\end{tabular}

Perttula et al. (2012) have reviewed the age and distribution of shell-tempered ceramics in Caddo sites across the southern Caddo area. In general, shell-tempered ceramics were made by East Texas Caddo potters only after ca. A.D. 1300, particularly in McCurtain phase sites along the middle reaches of the Red River and the lower Kiamichi River in southeastern Oklahoma. In the mid-Sabine River basin in East Texas, shell-tempered sherds are found only in low proportions in post-A.D. 1680 contexts, and it is suspected that these shell-tempered vessels found in Historic Caddo period contexts were made on the Red River in Northwest Louisiana by Caddo potters and traded to Nadaco Caddo groups that were living in the Sabine River basin until the early $19^{\text {th }}$ century.

The Arnold WPA sherd collection from the Kinsloe site includes 60 decorated sherds (see Table 1), 88 percent from utility ware vessels and the remaining 12 percent from fine ware vessels. Of the decorated sherds in this collection, the most common decorative methods are brushed ( 33.3 percent of all the decorated sherds) and brushed sherds with other decorative elements (i.e., incised and punctated, 10.0 percent), punctated (23.3 percent), incised-punctated (11.7 percent), and engraved (10.0 percent) (Table 2 and Figure 7a-b). The only rim sherd in the collection has an incised-punctated motif (Figure 8b).

Table 2. Decorative methods and elements represented in the sherds from Arnold's WPA collections from the Kinsloe site.

\begin{tabular}{llll}
\hline Decorative method/elements & Rim & Body & $\mathrm{N}$ \\
\hline
\end{tabular}

\section{Utility Ware}

\section{Brushed}

horizontal and diagonal brushed

horizontal and overlapping brushed

opposed brushed

overlapping brushed

parallel brushed

$\begin{array}{lll}- & 1 & 1 \\ - & 1 & 1 \\ - & 2 & 2 \\ - & 1 & 1 \\ - & 15 & 15\end{array}$

\section{Brushed-Incised}

curvilinear brushed and diagonal opposed incised lines curvilinear brushed-incised marks and lines parallel brushed and adjacent parallel incised lines

$\begin{array}{lll}- & 1 & 1 \\ - & 1 & 1 \\ - & 1 & 1\end{array}$

\section{Brushed-Incised-Punctated}

opposed brushed-incised marks and lines and overlying rows of fingernail punctations 
Table 2. Decorative methods and elements represented in the sherds from Arnold's WPA collections from the Kinsloe site, cont.

\begin{tabular}{llll}
\hline Decorative method/elements & Rim & Body & $N$ \\
\hline
\end{tabular}

\section{Utility Ware, cont.}

\section{Brushed-Punctated}

curvilinear brushed and curvilinear row of circular punctations horizontal brushed with tool punctated rows through the brushing

$\begin{array}{lll}- & 1 & 1 \\ - & 1 & 1 \\ - & 5 & 5 \\ - & & 1 \\ 1 & 1 & 1 \\ - & - & 1 \\ - & 1 & 1 \\ - & 1 & 1 \\ - & 1 & 1 \\ - & 1 & \end{array}$

\section{1}

1

\section{Incised}

parallel incised lines

Incised-Punctated

curvilinear incised lines and curvilinear rows of 1

tool punctates between incised lines

diagonal incised triangle el. filled with rows of circular punctates

horizontal and diagonal incised triangle el. filled with fingernail punctates

horizontal and diagonal incised triangle el. filled with tool punctates

horizontal incised lines on either side of a tool punctated row

horizontal and diagonal incised lines and single tool punctate at end of a diagonal incised line

tool punctated row and vertical incised line

\section{Punctated}

fingernail punctated rows

$\begin{array}{lll}- & 13 & 13 \\ - & 1 & 1\end{array}$

single tool punctate

\section{Fine Ware}

\section{Engraved}

curvilinear engraved lines

curvilinear and diagonal opposed engraved lines curvilinear and parallel engraved lines parallel engraved lines straight engraved line

$\begin{array}{lll}- & 2 & 2 \\ - & 1 & 1 \\ - & 1 & 1 \\ - & 1 & 1 \\ - & 1 & 1\end{array}$

\section{Slipped}

int./ext. red-slipped surfaces 


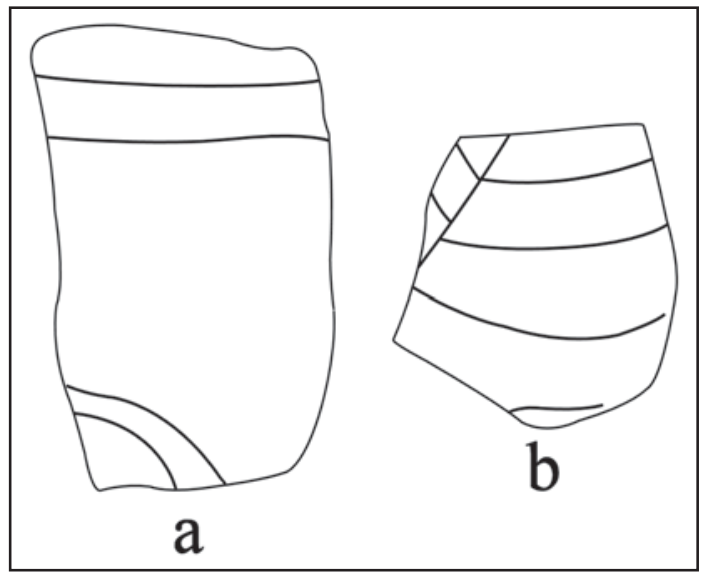

Figure 7. Selected decorative elements on engraved body sherds in the WPA collections from the Kinsloe site.

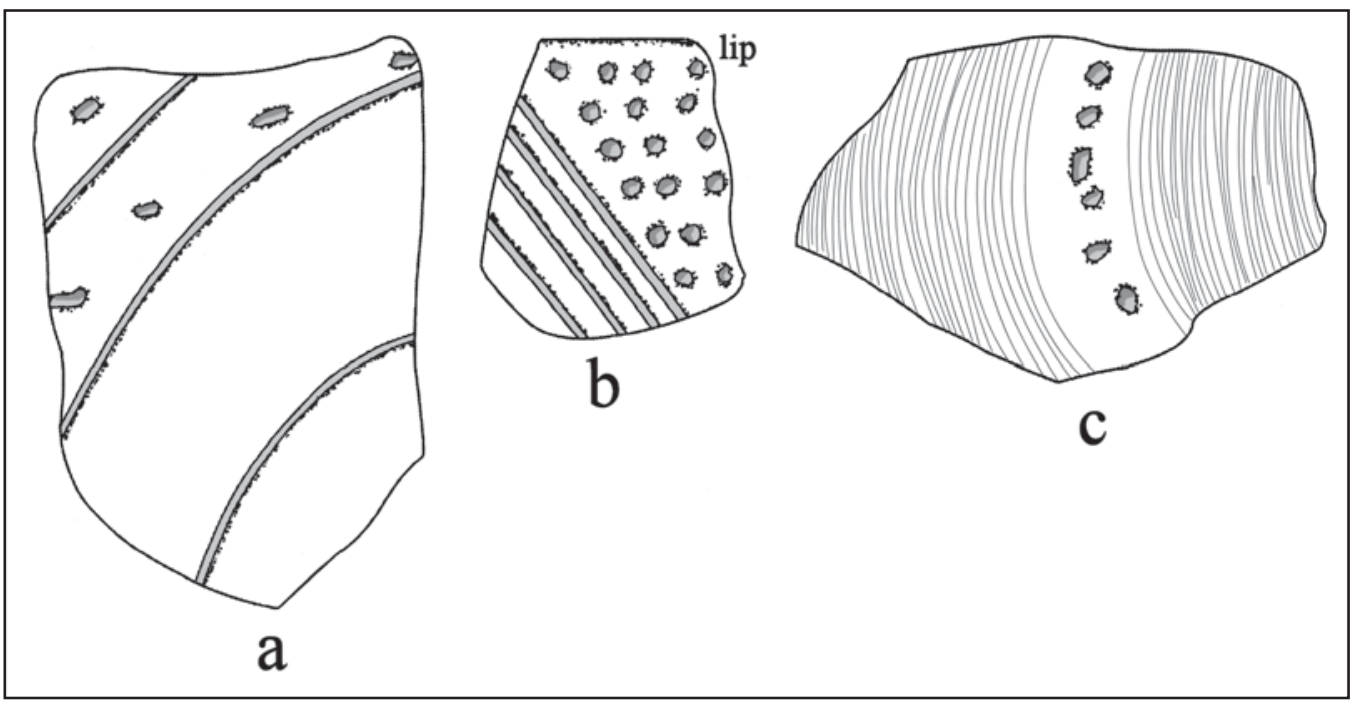

Figure 8. Selected decorative elements on utility ware rim and body sherds in the WPA collections from the Kinsloe site: a-b, incised-punctated; c, brushed-punctated.

In the non-shell-tempered decorated sherds, 42.6 percent of these sherds have brushed, brushedincised, brushed-incised-punctated, or brushed-punctated (see Figure 8c) decorative elements. In this part of the Sabine River basin, this proportion of brushed sherds among all the decorated sherds is consistent with a ca. A.D. 1300-1400 Caddo occupation, one contemporaneous with the early to middle part of the occupation at the Pine Tree Mound site (41HS15) (Gadus and Fields 2012:655, 660, and Table 9.2). In the later Titus phase occupation at the Pine Tree Mound site, 76 percent of all the decorated sherds have brushed decorative elements (Gadus and Fields 2012:Table 6.15).

Other non-shell-tempered decorated sherds from this Caddo component include body sherds with rows of either fingernail or tool punctations and incised-punctated sherds with incised triangle elements, and the incised triangle elements are filled with rows of either fingernail or tool punctations (see Figure $8 \mathrm{~b}$ ). One body sherd has curvilinear incised lines and curvilinear rows of tool punctates between incised lines (see Figure 8a). The few incised sherds from this component have only parallel incised lines (see Table 2). Among the fine wares in this probable Middle Caddo period component is one body sherd 
with a red slip on both interior and exterior vessel surfaces and four engraved body sherds. One has curvilinear engraved lines, another has curvilinear and diagonal opposed engraved lines (see Figure 7b), and the two other body sherds have either parallel or straight engraved lines.

Six of the 60 decorated sherds are from shell-tempered vessels. They include two sherds with parallel brushing marks, a lower rim-body sherd with horizontal brushing on the rim and diagonal brushing on the body, for a total of 50 percent with brushed decorative elements, a body sherd with parallel incised lines (probably from a Emory Punctated-Incised vessel), and two engraved body sherds. One of these is from a bottle sherd with curvilinear engraved lines, while the other has both curvilinear and parallel engraved lines (see Figure 7a). The shell-tempered brushed sherds may be from Red River or Ouachita River Mound Tract Incised and Brushed or Cowhide Stamped vessels (Kidder 1988; Kelley 1997:52; Webb 1959:128) dating from the mid- $17^{\text {th }}$ century to the early $18^{\text {th }}$ century A.D., or more likely from Red River-manufactured Karnack Brushed-Incised, var. Karnack jars from Historic Chakanina phase Caddo contexts (see Schambach and Miller 1984).

\section{Ceramic Pipes}

Arnold also documented two undecorated ceramic elbow pipes in the Fox collection from burial features at the Kinsloe site. Both are grog-tempered and have short stems relative to the height of the pipe bowl (Figure 9a-b). The larger of the two pipes is $4.6 \mathrm{~cm}$ in height, with a $5.7 \mathrm{~cm}$ bowl diameter; the overall length of the pipe is $6.2 \mathrm{~cm}$ (Figure 9a). The other pipe (Figure 9b) stands only $3.1 \mathrm{~cm}$ in height, has a $2.6 \mathrm{~cm}$ bowl diameter, and is $3.8 \mathrm{~cm}$ in length; the pipe bowl lip is $3 \mathrm{~mm}$ thick.

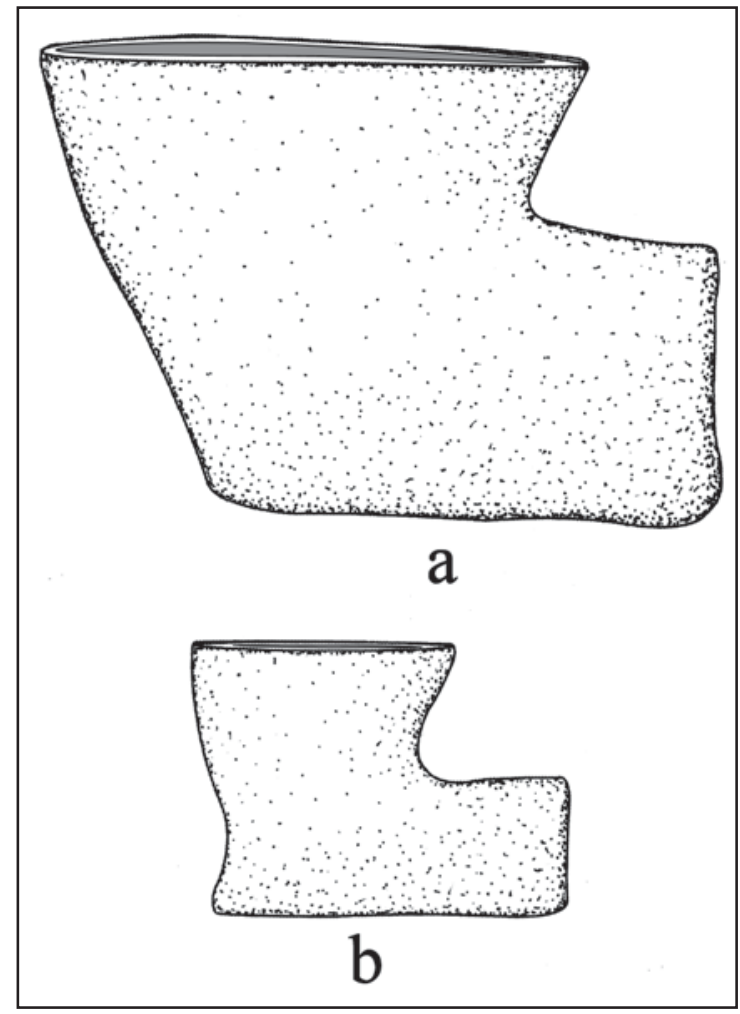

Figure 9. Elbow pipes from the Kinsloe site (41GG3). 


\section{Glass Beads}

Six drawn or tubular glass beads are in the Kinsloe site collection from the 1937 investigations. Two are small (3.3 mm in diameter) round white seed beads (IIa13 in Kidd and Kidd [1970], one is a medium blue round bead $(5.4 \mathrm{~mm}$ in diameter, IIa40), another is a large $(7.7 \mathrm{~mm}$ in diameter, IIa40) blue round bead, and the other two glass beads are very large $(15.2 \mathrm{~mm}$ in diameter) white tubular beads with either sets of one blue stripe (unidentified to bead type). or three sets of three blue stripes (Ib'2). The large striped beads such as the two tubular beads in the burial feature excavated by Hughes make their first appearance in 1700-1760 Native American sites, as is generally the case for colonial French Louisiana sites in the Southeast (Smith 2002).

\section{Marine Shell Beads}

There were five Buscyon sp. marine shell beads in the burial feature excavated by Hughes. They range from 56-65 $\mathrm{mm}$ in length and 8-9 $\mathrm{mm}$ in diameter. Jones (1968:40 and Plate 4e) documented three other marine shell beads from the site of the same size and character, and noted that "they are reported to have occurred infrequently in burials with the exact number being unknown."

\section{Bone Tool}

One polished bone tool was among the associated funerary offerings in the Caddo burial excavated by Jack Hughes in 1937. It is $77+x 7.1 \mathrm{~mm}$ in length and width, and has an abraded working edge, and may be a flaking tool.

\section{Red Ochre}

The piece of red ochre from the burial excavated in 1937 by Hughes is both polished and notched on several facets; it would have been a source of pigment for painting, tattooing, and for application to engraved designs on fine ware vessels. It is $50 \times 29$ x $19 \mathrm{~mm}$ in length, width, and thickness.

\section{Summary and Conclusions}

The Kinsloe site (41GG3) on Rabbit Creek in the mid-Sabine River basin in East Texas has been known to archaeologists since the 1930s. The site was found in 1931 when the Magnolia Oil Company graded an area of floodplain and alluvial fans for the construction of oil pipelines and storage tanks, and exposed a number of ancestral Caddo burial features. Employees of the company, in particular an E. A. Fox, proceeded to excavate as many as 29-30 burials in a large cemetery at the site between 1931-1937, as detailed by Jones (1968:29-47), recovering numerous funerary offerings, among them ceramic vessels, glass beads, and other European trade goods. Subsequent consideration and documentation of these funerary offerings indicates that these burial features are part of an $18^{\text {th }}$ century Nadaco Caddo cemetery, and the cemetery is just one of several other Nadaco sites in the mid-Sabine River basin. Jones (1968) included the sites in the Kinsloe focus/phase.

Jones (1968) documented the collections obtained by Mr. E. A. Fox at the site in 1958 and 1961, defined Areas A-D within the site - with the Nadaco Caddo cemetery in Area C-and recovered a small sample of artifacts from surface collections from other parts of the site. These surface collections allowed the recognition of a prehistoric Caddo component at the site in addition to the Nadaco Caddo cemetery area. Unbeknownst to Jones, other archaeologists had conducted investigations at the Kinsloe site in 1937 and 1940, and the records and collections from those investigations are curated at the Texas Archeological Research Laboratory at The University of Texas at Austin. 
In 1937, Jack T. Hughes, then a high school student, excavated a burial feature at the Kinsloe site. Among the funerary offerings were two shell-tempered vessels - a Natchitoches Engraved bowl and a cf. Ebarb Incised jar-Busycon sp. marine shell beads, 1700-1760 European glass beads, a polished bone tool, and a polished and notched piece of red ochre. In April 1940, as part of his archaeological survey of East Texas done under the auspices of the WPA, Gus E. Arnold visited and recorded the Kinsloe site, documented two other Natchitoches Engraved bowls - these in the E. A. Fox collection - along with several small plain jars and plain ceramic elbow pipes from Nadaco Caddo burial features, and obtained a surface collection of ancestral Caddo ceramic vessel sherds from unknown areas of the site. The character of the grog and bone-tempered vessel sherds in this assemblage of 129 sherds suggests that the initial Caddo occupation of the Kinsloe site took place in the Formative to Early Caddo periods (marked by thick Williams Plain base sherds), followed by a more substantial occupation in Middle Caddo period times, ca. A.D. 1300-1400. In this component, more than 42 percent of these sherds have brushed, brushed-incised, brushed-incised-punctated, or brushed-punctated decorative elements. In this part of the Sabine River basin, this proportion of brushed sherds among all the decorated sherds is consistent with a ca. A.D. 1300-1400 Caddo occupation, one contemporaneous with the early to middle part of the occupation at the Pine Tree Mound site (41HS15). The $18^{\text {th }}$ century Nadaco Caddo component at the Kinsloe site is represented in the vessel sherd assemblage by a few plain and decorated shell-tempered bottle, bowl, and jar sherds.

\section{Acknowledgments}

Thanks to the folks working at the Texas Archeological Research Laboratory for their help in locating the Kinsloe site collections there, especially Lauren Bussiere; thanks also to Jean Hughes for the scans of the 1940 vessel drawings. Lance Trask prepared the figures in this article. Patti Haskins of the Gregg County Historical Museum kindly supplied information on the collections obtained by Buddy C.

Jones from the Kinsloe site, and David B. Kelley made a useful suggestion regarding the shell-tempered brushed ceramic sherds found in the Kinsloe site collections.

\section{References Cited}

Fields, R. C. and E. F. Gadus (editors)

2012 Archeology of the Nadaco Caddo: The View from the Pine Tree Mound Site (41HS15), Harrison County, Texas. 2 Vols. Reports of Investigations No. 164. Prewitt and Associates, Inc., Austin.

Gadus, E. F. and R. C. Fields

2012 Ceramic Artifacts. In Archeology of the Nadaco Caddo: The View from the Pine Tree Mound Site (41HS15), Harrison County, Texas, edited by R. C. Fields and E. F. Gadus, pp. 387-551. 2 Vols. Reports of Investigations No. 164. Prewitt and Associates, Inc., Austin.

Gregory, H. F. and G. Avery

2007 American Indian Pottery from Historic Period Sites in North Louisiana. Journal of Northeast Texas Archaeology 26:33-76.

Im, H.-J.

1975 An Analysis of the G. E. Arnold Survey of East Texas. Master's thesis, Department of Anthropology, The University of Texas at Austin.

Jones, B. C.

1968 The Kinsloe Focus: A Study of Seven Historic Caddoan Sites in Northeast Texas. Master's thesis, Department of Anthropology, University of Oklahoma, Norman. 
Kelley, D. B. (editor)

1997 Two Caddoan Farmsteads in the Red River Valley. Research Series No. 51. Arkansas Archeological Survey, Fayetteville.

Kidd, K. E. and M. A. Kidd

1970 A Classification System for Glass Beads for the Use of Field Archaeologists. Canadian Historic Sites: Occasional Papers in Archaeology and History, No. 1, pp. 45-89. National Historic Sites Service, National and Historic Parks Branch, Department of Indian Affairs and Northern Development, Ottawa, Ontario.

Kidder, T. R.

1988 Protohistoric and Early Historic Culture Dynamics in Southeast Arkansas and Northeast Louisiana. Ph.D. dissertation. Department of Anthropology, Harvard University, Cambridge.

Perttula, T. K.

2007 Kinsloe Focus Artifact Assemblages and Nadaco Caddo. Journal of Northeast Texas Archaeology 26:116119.

Perttula, T. K., M. B. Trubitt, and J. S. Girard

2012 The Use of Shell-Tempered Pottery in the Caddo Area of the Southeastern United States. Southeastern Archaeology 30(2):242-267.

Schambach, F. F. and J. E. Miller

1984 A Description and Analysis of the Ceramics. In Cedar Grove: An Interdisciplinary Investigation of a Late Caddo Farmstead in the Red River Valley, edited by N. L. Trubowitz, pp. 109-170. Research Series No. 23. Arkansas Archeological Survey, Fayetteville.

Smith, M. T.

2002 Eighteenth-Century Glass Beads in the French Colonial Trade. Historical Archaeology 36(1):55-61.

Webb, C. H.

1959 The Belcher Mound, a Stratified Caddoan Site in Caddo Parish, Louisiana. Memoirs No. 16. Society for American Archaeology, Salt Lake City. 